\title{
Front Matter: Volume 9296
}

, "Front Matter: Volume 9296," Proc. SPIE 9296, International Symposium on Optoelectronic Technology and Application 2014: Advanced Display Technology; Nonimaging Optics: Efficient Design for Illumination and Solar Concentration, 929601 (3 December 2014); doi: 10.1117/12.2179829

SPIE Event: International Symposium on Optoelectronic Technology and SPIE. Application 2014, 2014, Beijing, China 


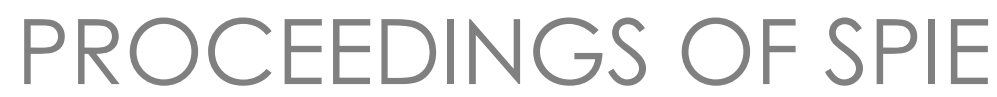

\title{
International Symposium on Optoelectronic Technology and Application 2014:
}

\section{Advanced Display Technology; and Nonimaging Optics: Efficient Design for Illumination and Solar Concentration}

\author{
Byoungho Lee \\ Ting-Chung Poon \\ Yongtian Wang \\ Yong Bi \\ Roland Winston \\ Yi Luo \\ Editors
}

13-15 May 2014

Beijing, China

Organized by

Photoelectronic Technology Committee, Chinese Society of Astronautics (China)

Sponsored by

Chinese Society of Astronautics (China)

China High-tech Industrialization Association (China)

Technical Cosponsor and Publisher

SPIE

Volume 9296 
The papers included in this volume were part of the technical conference cited on the cover and title page. Papers were selected and subject to review by the editors and conference program committee. Some conference presentations may not be available for publication. The papers published in these proceedings reflect the work and thoughts of the authors and are published herein as submitted. The publisher is not responsible for the validity of the information or for any outcomes resulting from reliance thereon.

Please use the following format to cite material from this book:

Author(s), "Title of Paper," in International Symposium on Optoelectronic Technology and Application 2014: Advanced Display Technology; and Nonimaging Optics: Efficient Design for Illumination and Solar Concentration, edited by Byoungho Lee, Ting-Chung Poon, Yongtian Wang, Yong Bi, Roland Winston, Yi Luo, Proceedings of SPIE Vol.9296 (SPIE, Bellingham, WA, 2014) Article CID Number.

ISSN: 0277-786X

ISBN: 9781628413823

Published by

SPIE

P.O. Box 10, Bellingham, Washington 98227-0010 USA

Telephone +13606763290 (Pacific Time) · Fax +13606471445

SPIE.org

Copyright (C) 2014, Society of Photo-Optical Instrumentation Engineers.

Copying of material in this book for internal or personal use, or for the internal or personal use of specific clients, beyond the fair use provisions granted by the U.S. Copyright Law is authorized by SPIE subject to payment of copying fees. The Transactional Reporting Service base fee for this volume is $\$ 18.00$ per article (or portion thereof), which should be paid directly to the Copyright Clearance Center (CCC), 222 Rosewood Drive, Danvers, MA 01923. Payment may also be made electronically through CCC Online at copyright.com. Other copying for republication, resale, advertising or promotion, or any form of systematic or multiple reproduction of any material in this book is prohibited except with permission in writing from the publisher. The CCC fee code is 0277-786X/14/\$18.00.

Printed in the United States of America.

Publication of record for individual papers is online in the SPIE Digital Library.

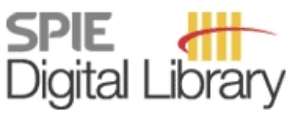

SPIEDigitalLibrary.org

Paper Numbering: Proceedings of SPIE follow an e-First publication model, with papers published first online and then in print and on CD-ROM. Papers are published as they are submitted and meet publication criteria. A unique, consistent, permanent citation identifier (CID) number is assigned to each article at the time of the first publication. Utilization of CIDs allows articles to be fully citable as soon as they are published online, and connects the same identifier to all online, print, and electronic versions of the publication. SPIE uses a six-digit CID article numbering system in which:

- The first four digits correspond to the SPIE volume number.

- The last two digits indicate publication order within the volume using a Base 36 numbering system employing both numerals and letters. These two-number sets start with 00, 01, 02, 03, 04, 05, 06, 07, 08, 09, OA, OB ... 0Z, followed by 10-1Z, 20-2Z, etc.

The CID Number appears on each page of the manuscript. The complete citation is used on the first page, and an abbreviated version on subsequent pages. Numbers in the index correspond to the last two digits of the six-digit CID Number. 


\title{
Contents
}

\author{
$\checkmark \quad$ Authors \\ vii Symposium Committees \\ xi Conference Committee \\ xiii Introduction
}

\section{ADVANCED DISPLAY TECHNOLOGY AND APPLICATION}

929602 Real-time integral imaging system with handheld light field camera (Invited Paper) [9296-8]

929603 Development of full color holographic optical element recorded on aspherical substrate with photopolymer (Invited Paper) [9296-15]

929604 Holographic color imaging of incoherent three-dimensional objects by off-axis Fourier triangular digital holography [9296-29]

929605 CMOS compatible avalanche photodetector and its application in communications [9296-12]

929606 Optimize the modulation response of twisted-nematic liquid crystal displays as pure phase spatial light modulators [9296-4]

929607 Ultra-wide fast fisheye for security and monitoring applications [9296-1]

929608 Aviation spectral camera infinity target simulation system [9296-27]

929609 Study of improved ray tracing parallel algorithm for CGH of 3D objects on GPU [9296-13]

9296 OA Design of multi-mode compatible image acquisition system for HD area array CCD [9296-25]

9296 OB A method of rapidly evaluating image quality of NED optical system [9296-10]

9296 OC The development and outlook of variable-focus lens [9296-23]

9296 OD High-definition video display based on the FPGA and THS8200 [9296-24]

9296 OE Colorized linear CCD data acquisition system with automatic exposure control [9296-26]

9296 OF Application of real image display and generation technique in space optical system [9296-28]

9296 OG Research on the aero-thermal effects by 3D analysis model of the optical window of the infrared imaging guidance [9296-22] 
$9296 \mathrm{OH}$ Research and analysis on the thin films sputtered by the Ba-AI-S:Eu target fabricated by powder sintering [9296-16]

$929601 \quad H i g h-p o w e r$ and efficient Nd:YVO4/PPMgLN arrayed green laser for laser display [9296-9]

9296 0J Investigation of homogenizing the light field in laser display [9296-18]

9296 OK Blue phase liquid crystalline polymers and its application in manned spacecraft [9296-19]

9296 OL Numerical analysis on imaging character of a single microsphere [9296-31]

$92960 \mathrm{M} \quad 5 \mathrm{~W}$ intracavity frequency-doubled green laser for laser projection [9296-21]

\section{NONIMAGING OPTICS: EFFICIENT DESIGN FOR ILLUMINATION AND SOLAR CONCENTRATION}

9296 ON Design of beam expander for 90-nm lithography tool [9296-101]

929600 Fresnel lens solar beam convergence properties [9296-106]

9296 OP Design of chirped fly's eye uniformizer for Arf lithography illumination system [9296-108]

$92960 Q \quad$ Single-pulse femtosecond laser Bessel beams drilling of high-aspect-ratio microholes based on electron dynamics control [9296-109] 


\section{Authors}

Numbers in the index correspond to the last two digits of the six-digit citation identifier (CID) article numbering system used in Proceedings of SPIE. The first four digits reflect the volume number. Base 36 numbering is employed for the last two digits and indicates the order of articles within the volume. Numbers start with 00, 01, 02, 03, 04, 05, 06, 07, 08, 09, OA, OB...0Z, followed by 10-1Z, 20-2Z, etc.

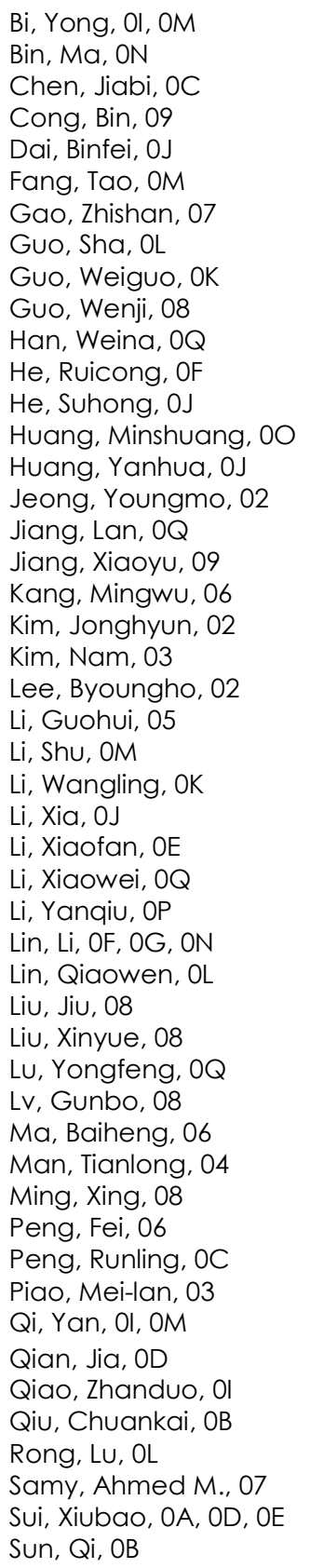

Tang, Miangang, 05

Tian, Feng, $0 \mathrm{O}$

Wan, Yuhong, 04

Wang, Chen, OA

Wang, Dayong, OL

Wang, Dongdong, OM

Wang, Dongzhou, OM

Wang, Yu, OI

Wang, Yunxin, OL

Wei, Lidong, OP

Wei, Maowei, OC

Wu, Chengguo, OJ

Wu, Hui-Ying, 03

Wu, Zhigang, 05

Xia, Bo, $O Q$

Xiao, Lei, OP

Xing, Han, ON

$X \cup, B O, O G$

$\mathrm{XU}$, Fang, $\mathrm{OH}, \mathrm{OK}$

$\mathrm{Xue}, \mathrm{Wei}, \mathrm{OH}$

Yan, Boxia, OI, OM

Yan, Xueliang, $O Q$

Yang, Huan, $O B$

Yao, Jun, 09

Yeom, Jiwoon, 02

$\mathrm{Yu}$, Zhinong, $\mathrm{OH}$

Zhang, Dongpu, $\mathrm{OH}, \mathrm{OK}$

Zhao, Kai, 09

Zhao, Weiwei, $O Q$

Zhou, Jiawu, 06

Zhu, Ying, $0 G$

Sun, Qi, OB 
Proc. of SPIE Vol. $9296929601-6$

Downloaded From: https://www.spiedigitallibrary.org/conference-proceedings-of-spie on 26 Apr 2023 Terms of Use: https://www.spiedigitallibrary.org/terms-of-use 


\title{
Symposium Committees
}

\author{
Symposium Chairs
}

Guofan Jin, Tsinghua University (China)

Songlin Zhuang, University of Shanghai for Science and Technology (China)

\section{Conference Committee}

Bingheng Lu, Xi'an Jiaotong University (China)

Byoungho Lee, Seoul National University (Republic of Korea)

Daren Lv, Institute of Atmospheric Physics (China)

David Webb, Aston University (United Kingdom)

Dianyuan Fan, Shanghai Institute of Optics and Fine Mechanics (China)

Feng Zhang, Academy of Chinese Aerospace Science and Industry Feihang Technology (China)

Gaurav Sharma, University of Rochester (United States)

Guangjun Zhang, Beihang University (China)

Huitao Fan, Luoyang Optoelectro Technology Development Center (China)

Huixing Gong, Shanghai Institute of Technical Physics (China)

Jannick Rolland, University of Rochester (United States) and LighTopTech Corporation (United States)

Jianquan Yao, Tianjin University (China)

Jiaqi Wang, Changchun Institute of Optics, Fine Mechanics and Physics (China)

Jingshan Jiang, Center for Space Science and Applied Research (China)

Junhao Chu, Shanghai Institute of Technical Physics (China)

Lijun Wang, Changchun Institute of Optics, Fine Mechanics and Physics (China)

Lin Li, Laser Processing Research Centre, The University of Manchester (United Kingdom)

Liwei Zhou, Beijing Institute of Technology (China)

Ming C. Leu, Missouri University of Science and Technology (United States)

Norbert Kaiser, Fraunhofer Institute for Applied Optics and Precision Engineering (Germany)

Qifeng Yu, National University of Defense Technology (China)

Qingxi Tong, The Institute of Remote Sensing and Digital Earth (China)

Shouhuan Zhou, North China Research Institute of Electro-optics (China) 
Tianchu Li, National Institute of Metrology (China)

Ting-Chung Poon, Virginia Polytechnic Institute and State University (United States)

Wei Wang, Beijing Institute of Aerospace Control Devices (China)

Zuyan Xu, The Technical Institute of Physics and Chemistry (China)

Program Committee

Songlin Zhuang, Chair, University of Shanghai for Science and Technology (China)

Huaming Wang, Co-chair, Beihang University (China)

Huikai Xie, Co-chair, University of Florida (United States)

Jannick Rolland, Co-chair, University of Rochester (United States)

Jürgen Czarske, Co-chair, Technische Universität Dresden

(Germany)

Yongtian Wang, Co-chair, Beijing Institute of Technology (China)

Anatoli G. Borovoi, V.E. Zuev Institute of Atmospheric Optics

(Russian Federation)

Bincheng Li, Institute of Optics and Electronics (China)

Binghen Lu, Xi'an JiaoTong University (China)

Byoungho Lee, Seoul National University (Republic of Korea)

Changxiang Yan, Changchun Institute of Optics, Fine Mechanics and Physics (China)

Dae Wook Kim, The University of Arizona (United States)

David Webb, Aston University (United Kingdom)

Dawei Zhang, University of Shanghai for Science and Technology (China)

Dong Liu, Anhui Institute of Optics and Fine Mechanics (China)

Fugen Zhou, Beijing University of Aeronautics and Astronautics (China)

Gaurav Sharma, University of Rochester (United States)

Geert Verhaeghe, Faurecia Autositze GmbH (Germany)

Guangya Zhou, National University of Singapore (Singapore)

Haimei Gong, Shanghai Institute of Technical Physics (China)

Jin Lu, Tianjin Jinhang Institute of Technical Physics (China)

Jun Zhou, Shanghai Institute of Optics and Fine Mechanics (China)

Kai Cheng, Brunel University (United Kingdom)

Ligong Zheng, Changchun Institute of Optics Fine Mechanics and Physics (China)

Lijun Wang, Changchun Institute of Optics, Fine Mechanics and Physics, (China)

Lin Li, Laser Processing Research Centre, The University of Manchester (United Kingdom)

Ming C. Leu, Missouri University of Science and Technology (United States)

Minlin Zhong, Tsinghua University (China)

Mircea Guina, Tampere University of Technology (Finland) 
Norbert Kaiser, Fraunhofer Institute for Applied Optics and Precision Engineering (Germany)

Pu Wang, Beijing University of Technology (China)

Roland Winston, University of California (United States)

Rongbing W. B. Lee, The Hong Kong Polytechnic University (Hong Kong, China)

Shulian Zhang, Tsinghua University (China)

Ting-Chung Poon, Virginia Polytechnic Institute and State University (United States)

Wei Wang, Beijing Institute of Aerospace Control Devices (China)

Wenli Ma, The Institute of Optics and Electronics (China)

Yi Luo, Tsinghua University (China)

Yiqin Ji, Tianjin Jinhang Institute of Technical Physics (China)

Yong Bi, Academy of Opto-electronics (China)

Yong Cheng, Wuhan Ordnance Non-Commissioned Officers Academy (China)

Yongnian Yan, Jiangsu YONGNIAN Laser Forming Technology Company, Ltd. (China)

Zhichuan Niu, Institute of Semiconductors (China) 
Proc. of SPIE Vol. $9296929601-10$

Downloaded From: https://www.spiedigitallibrary.org/conference-proceedings-of-spie on 26 Apr 2023 Terms of Use: https://www.spiedigitallibrary.org/terms-of-use 


\title{
Conference Committee
}

\author{
Conference Chairs
}

Byoungho Lee, Seoul National University (Korea, Republic of)

Ting-Chung Poon, Virginia Polytechnic Institute and State University (United States)

Yongtian Wang, Beijing Institute of Technology (China)

Yong Bi, Academy of Opto-Electronics (China)

Roland Winston, University of California, Merced (United States)

Yi Luo, Tsinghua University (China) 
Proc. of SPIE Vol. $9296929601-12$

Downloaded From: https://www.spiedigitallibrary.org/conference-proceedings-of-spie on 26 Apr 2023 Terms of Use: https://www.spiedigitallibrary.org/terms-of-use 


\section{Introduction}

We had the great honor of organizing the International Symposium on Optoelectronic Technology and Application 2014 (IPTA 2014) in Beijing. It was truly a great pleasure for us to greet nearly 1,000 participants from many different countries attending IPTA 2014! We firmly believe that the symposium will become an important international event in the field of photoelectronic technology.

IPTA 2014 was sponsored by Chinese Society of Astronautics (CSA) and China Hightech Industrialization Association, technically co-sponsored by SPIE, and organized by Photoelectronic Technology Committee, Chinese Society of Astronautics. 27 cooperating organizations supported the conference. There were nearly 600 papers accepted for presentation at IPTA 2014, contributed by over 1078 authors from more than 10 countries, including United States, United Kingdom, Germany, France, Norway, Australia, Canada, Japan, Korea, Russia, and China. We had six plenary speeches and 228 well-known scientists and experts, from both home and abroad to give invited talks at different sessions.

The purpose of IPTA 2014 was to provide a forum for the participants to report and review innovative ideas, with up-to-date progress and developments, and discuss the novel approaches to application in the field of photoelectronic technology. We sincerely hope that the research and development in the optical and photoelectronic fields will be promoted, and international cooperation sharing the common interest will be enhanced.

On behalf the Organization Committee of IPTA 2014, we would like to heartily thank our sponsors and cooperating organizations for all they have done for the conference. We would also like to thank the authors for their contribution to the proceedings; the participants and friends of IPTA 2014, for their interest and efforts in helping us to make the symposium possible; and the Program Committee for their effective work and valuable advice, especially the IPTA 2014 Secretariat and the SPIE staff, for their tireless efforts and outstanding services in preparing the conference and publishing the Proceedings.

\section{Guofan Jin \\ Songlin Zhuang \\ IPTA 2014 Symposium Committee Chairs}


Proc. of SPIE Vol. $9296929601-14$

Downloaded From: https://www.spiedigitallibrary.org/conference-proceedings-of-spie on 26 Apr 2023 Terms of Use: https://www.spiedigitallibrary.org/terms-of-use 